\title{
Is there any economics in smallholder cocoyam production? Evidence from the forest agro-ecological zone of Ghana
}

\author{
Stanley Boakye-Achampong ${ }^{1 *}\left(\mathbb{D}\right.$, Kwasi Ohene-Yankyera $^{1}$, Robert Aidoo ${ }^{1}$ and Olav Jull Sørensen ${ }^{2}$
}

\begin{abstract}
Background: Cocoyam is an important food security crop in Ghana because it stores better than all other root and tuber crops. Despite its socio-economic relevance, production has declined persistently since the last decade. This study attempts to examine the profitability of cocoyam production to smallholders in Ghana by estimating the returns on critical production resources. Using a multi-stage sampling technique, 150 cocoyam producers were randomly sampled across three major producing regions in Ghana.
\end{abstract}

Results: Empirical results reveal that cocoyam production is generally not profitable given the present cost of capital in Ghana, suggesting why farmers are shifting from its production. A disaggregated analysis reveals that producers in Fanteakwa district have a competitive advantage over their counterparts in Asante Akyem South and Asunafo North districts in terms of relative profitability owing to higher yield and better produce price at terminal markets. Gross margin, net profit, and returns on assets, land as well as unpaid labour and management significantly varied across districts. Producing cocoyam on sole crop basis was found to significantly return higher than the predominant intercropping culture of production. Apart from production cost, gross margins, net income and returns to critical production factors under the mono-cropping system were found to be significantly higher, at 5\% significance level, compared to the intercropping system.

Conclusion: The study concludes that smallholder cocoyam production is presently not profitable, and hence, production scales have reduced to subsistence levels. Due to higher yield and better produce prices, Fanteakwa farmers have a competitive advantage over other producing districts. Production under the mono-cropping system is relatively profitable than under the intercropping system. However, the financial leverage of cocoyam production could be enhanced via policy alternatives directed at ensuring farmers' access to and intensification of productive inputs.

Keywords: Cocoyam, Profitability, Return on assets, Cropping systems, Ghana

\section{Background}

Food security has been a prime sustainable development issue over the last decade, especially for developing countries like Ghana. In order to achieve SDG 2, Ghana has taken keen interest in the performance of the root and tuber subsector vis-à-vis its enormous contributions towards poverty reduction and attainment of food

\footnotetext{
*Correspondence: sbabigstan@gmail.com

1 Department of Agricultural Economics, Agribusiness and Extension, Kwame Nkrumah University of Science and Technology (KNUST), Private Mail Bag, Kumasi, Ghana

Full list of author information is available at the end of the article
}

security. Cocoyam (Xanthosoma sagittifoluim.), commonly known as tannia, is a well-known food security crop due to its better storability compared to the other root and tuber crops. The root crop plays an important role in the livelihood of rural and urban dwellers because it is a major source of dietary calories and income, especially in times of food shortage and economic stress $[1,2]$.

However, production of the crop is experiencing a negative growth culminating in a contraction of the cocoyam subsector. National production statistics show that between 1999 and 2012, cocoyam production dropped by as much as $19.3 \%$, i.e. from 1.6 million metric tonnes 
to 1.27 million metric tonnes [3-5]. Whereas the areas under cultivation for policy-prioritised crops have significantly increased between 2000 and 2012 (58\% for maize; $31.6 \%$ for cassava; $63.3 \%$ for yam; and $38 \%$ for plantain), a reverse trend is rather observed for areas under cocoyam cultivation (a reduction of about 21\% within the same period) as listed in Table 1 [3]. This seems to suggest that cocoyam farmers are shifting from cocoyam to the cultivation of more competitive crops.

The high cost of production mainly due to the high labour requirement during cultivation amid the use of indigenous planting materials, application of total weed killers as well as limited value addition have led to a general decline of the cocoyam subsector. Other researchers such as Onyeka [1], Quaye et al. [5] and Talwana et al. [6] have also pinned the decline to costly production to high rent on agricultural land due to scarcity of same. They assert that these costs adversely impact on their profits and hence make it difficult for producing households to engage in production.

However, high rent on agricultural land is not exclusive to cocoyam production and hence cannot adequately explain the decline in cocoyam production. The phenomenon also affects other crops such maize, yam, cassava and plantain that have experienced increased cultivated area (Table 1).

Until recently, cocoyam had not been the focus of agricultural policy makers and stakeholders. But, some attempts have been made by policy makers and development practitioners at promoting its production in Ghana. The interventions have come by way of research, advocacy and innovation. The Root and Tuber Improvement Programme (RTIP); Root and Tuber Improvement and Marketing Programme (RTIMP); and the West Africa Agricultural Productivity Programme (WAAPP) are examples of such interventions [7-9]. However, evidence of their impact on cocoyam production and the cocoyam value chain is mixed probably due to lack of proper targeting of program beneficiaries or inadequate dissemination of technologies. Cocoyam cultivation continues to be characterised by the use of indigenous planting materials, high labour-intensive production with a lack of nutrient replacement strategies which otherwise could enhance yield and returns of smallholder farmers.
An effective agricultural system characterised by efficient production regimes, vibrant value addition and distribution networks as well as corresponding rewards to all stakeholders is ideal. Addressing problems in the cocoyam subsector will provide reliable alternative source of livelihood and food security for especially farmers as well as rural Ghana which constitute $48 \%$ of Ghana's population [10]. This role of cocoyam as a significant alternative food source is further entrenched by the recent fast transformation of cassava into an industrial and cash crop according to the Ghana Statistical Service [11], which directly has implications on food security in Ghana. As industrial demand for cassava continues to grow, its price and unavailability at the household level may rise, leaving consumers with the choice of relying more on cocoyam as an affordable alternative food source in preparing their $f u f u$ and ampesi dishes. If cocoyam production declines in the wake of industrial demand of cassava, access to affordable staples, especially to poor homes, will be negatively affected, thus reducing food security in the long run. Aside the implication of production decline on food and income security, it is imperative to draw the attention of policy makers to the status quo in the cocoyam subsector because with an annual average decline of $1.75 \%$ in area under cocoyam cultivation, using production data from 2000 to 2012 [3], the root crop may face possible total extinction from the nation's agrarian landscape by the year 2057, ceteris paribus.

Currently, there is a paucity of empirical evidence in Ghana regarding the dynamics and economics of cocoyam production. Unlike other traditional root and tuber crops, i.e. cassava and yam, few empirical studies have been conducted on cocoyam in Ghana. These studies, for instance Quaye et al. [5] and Acheampong et al. [7], however, did not focus specifically on the economics of cocoyam, while others were based only on data from experimental plots $[12,13]$ and hence are probably not representative of the average cocoyam farmer.

Further, these studies have focused mainly on improved agronomic practises under the assumption that the improvements will result in higher yields and enhance the growth of the subsector. However, cocoyam competes with other crops like maize, yam and cassava for the same key resources (land, labour and capital).

Table 1 Area under cultivation of selected major crops in Ghana: 2000-2012 ('000 hectares)

\begin{tabular}{|c|c|c|c|c|c|c|c|c|}
\hline Crop/year & 2000 & 2002 & 2004 & 2006 & 2008 & 2010 & 2012 & \% change \\
\hline Maize & 647.5 & 939.6 & 732.9 & 793 & 846.3 & 954.4 & 1023.2 & 58.0 \\
\hline Cassava & 660.1 & 794.4 & 783.9 & 790 & 839.9 & 875 & 868.5 & 31.6 \\
\hline Cocoyam & 247.5 & 282.2 & 269.5 & 260 & 251.9 & 205.3 & 196.3 & -20.7 \\
\hline Yam & 261 & 300 & 310.9 & 325 & 347.6 & 384.9 & 426.3 & 63.3 \\
\hline Plantain & 244.4 & 276.9 & 281.2 & 299 & 311.8 & 328 & 337.3 & 38.0 \\
\hline
\end{tabular}


As these resources become increasingly unavailable, their opportunity cost in alternative employment surges. Hardly any studies have explored these dynamics; thus, this paper aims to contribute to the growing national discussion on cocoyam production by investigating its profitability in terms of financial returns to critical resources like capital, land and labour and management. These evidences are required so as to guide future policy decisions. The rest of the paper is divided into four sections: The second section reviews literature on cocoyam production in Ghana, its associated constraints as well as empirical studies on cocoyam profitability. The third section takes a looks at methodology adopted for the study. The fourth section presents the results of the profitability analysis. The final section, section five, presents conclusions and recommendations.

\section{Profitability of cocoyam production}

Several analysis on profitability of cocoyam production have been conducted by researchers like Onyeka [1], Quaye et al. [5], Acheampong et al. [7], Falola et al. [14] and Gbigbi [15]. These studies did not focus on assessment of profitability as a central theme of their respective studies but as a complementary assessment necessary for drawing relevant conclusions based on the central themes. Other studies such as Quaye et al. [5] and Talwana et al. [6] have ended up with gross margin analysis without relating profitability to the returns to key resources. Quaye et al. [5] employed the gross margin approach to assess costs and returns of cocoyam production. The study found that for each hectare of cocoyam farm, the total cost of production and total revenue were $\$ 669$ and $\$ 1426$, respectively, with labour constituting $80 \%$ of the total variable cost. Farmers earned a net revenue of $\$ 757$ per hectare. The study concluded that cocoyam production was profitable.

Sagoe et al. [13] also explored profitability of cocoyam under two cropping systems (mono-cropping and intercropping systems) using data from experimental plots. The study found out that the gross margin for solecropped cocoyam was higher than that for mix-cropped cocoyam. The study concluded that site-wise cocoyam experimental plots were economically viable and profitable on the basis of cost-benefit ratio of more than one. However, the recommendation for farmers to go for sole crop cocoyam production rather than mixed cropping system is untenable because their analysis did not account for the opportunity cost of associated crops in the mixed crop enterprise, which was absent in the sole crop production.

Studies by Gbigbi [15], Adepoju and Awodunmuyila [16], Ajijola et al. [17], and Okoye et al. [18] employed gross margin analysis and concluded that cocoyam production was profitable although there were notable differences in levels of profits made by cocoyam farmers in the various studies. These studies, however, did not address the question of cocoyam profitability in relation to other crops that compete for the same resources. It is possible that cocoyam production is declining because the returns to other competing crops are higher. Furthermore, most of the studies are silent on the contribution of revenue from cocoyam leaves to the total revenue accrued from cocoyam production. Cocoyam leaves were either bulked together with revenue from corms or totally ignored as evident in Quaye et al. [5], Sagoe et al. [13] and Okoye et al. [18]. This could result in an underestimation of the effective financial benefits that cocoyam farmers receive. The overwhelming evidence of cocoyam being profitable therefore begs the question why production continues to decline with reducing areas under cultivation in Ghana. The current study seek to fill this gap in knowledge.

Again, estimation of return on investment or asset for cocoyam in studies like Ajijola et al. [17] and Okoye et al. [18] seemed inaccurate, given that profit from cocoyam production was compared to total production cost rather than the average total assets used in generating profit for the cocoyam enterprise. This could result in the overestimated return on investment. Most of the studies reviewed ended their profitability analysis after estimating either gross margins or the net farm profit from production, which according to Beattie [19] is only a starting point of analysing profitability of farm enterprises. Empirical literature on the returns to critical resources like capital, labour and land for cocoyam production is largely scarce. Detailed profitability analysis that includes the use of indicators like return on assets (investment), return to land and return to labour and management would give a clearer picture of profitability of cocoyam enterprises relative to assets used in generating the profit.

\section{Research methods}

\section{Study area, sampling and data source}

The study employed the multi-stage sampling procedure in the selection of observation units. First, three major producing districts were purposively selected from the three major producing regions of Ghana. The selection process was based on the national- and district-level production intensity of cocoyam. The sampled districts were Asunafo North, Asante Akyem South and Fanteakwa Districts from the Brong Ahafo Region, Ashanti Region and Eastern Region of Ghana, respectively. All districts fall within the moist semi-deciduous forest agro-ecological zone of Ghana, the zone most suitable for cocoyam production. Using the simple random sampling technique, five communities were selected from 
each of the three districts. Using a sampling frame of 246 registered cocoyam producers, a total sample size of 150 was required to ensure representativeness within plus or minus $5 \%$ of the true prevalence at $95 \%$ confidence level and $100 \%$ response rate. For the purposes of practical sampling size determination, the study restricted the sampling to the current list of registered cocoyam producers, which were available at the respective agricultural district directorates at the time of data collection, i.e. 82 registered cocoyam producers per district. With assistance from the MoFA directorates within the aforementioned districts, cocoyam-producing communities were listed followed by a random selection of five communities from each district through balloting. Ten cocoyam producers were subsequently selected from each of the fifteen communities through simple random sampling technique, resulting in a total of 150 respondents. The list of cocoyam producers in these communities was obtained through the assistance of agricultural extension agents assigned to the selected communities. The essence of the random sampling was to ensure that each unit (farmer) had equal probability of being chosen, hence ensuring a highly representative sample and reducing human bias. Data were obtained through interviews with the aid of structured questionnaire. The data collected include information on cocoyam production and marketing (e.g. input use, costs, yields and output prices) and household farm-level characteristics (e.g. farm size, age, education).

\section{Analytical framework}

Both descriptive and inferential statistics were employed in the study to analyse the socio-economic and farm-level characteristics of cocoyam farmers. Costs and returns associated with cocoyam production were examined using gross margin technique, whereas profitability assessment was done using return to resources (capital, land and labour and management) computations. Kay et al. [20] defined gross margin as the difference between income and variable cost. Mathematically, it is expressed as:

$$
\mathrm{GM}=\sum_{j=1}^{m} P_{j} Y_{j}-\sum_{i=1}^{n} P_{i} X_{i}
$$

$\mathrm{P}_{j}$ denotes the market price per unit of output, $\mathrm{Y}_{j}$ denotes the quantity of output. $\mathrm{X}_{i}$ and $\mathrm{P}_{i}$ denote quantity of variable inputs used in cocoyam production and price of each variable input, respectively, whereas $i, j \ldots$ $n, m$ represent the total sample size. To estimate the net farm income, depreciation on farm assets were imputed as part of cost of production.

Operationally, the cost of depreciation of a farm asset was defined as the cost of the asset spread over its useful economic life [20,21]. Depreciation was imputed on farm assets like knapsack sprayer, hoes and metal basins since their average useful life stretched beyond a year. The study assumed based on observations on the field that such farm assets had zero economic value after their useful years. In other words, in the computation of depreciation, the farm assets were assumed to have no salvage value. This follows the argument by McConnel and Dillon [22] that smallholder farm assets practically have no salvage value. Hence, using the straight-line method, the operational expression for depreciating farm assets was:

$$
\text { Annual depreciation }=\frac{\text { Assetcost }}{\text { Years of useful life }}
$$

Furthermore, the net farm profit was computed to know how much is returned to cocoyam producers after marketing their produces. Net farm income (NFI), also known as net farm profit, reflects the revenue left after adjusting for fixed costs like rent on land, cost of equipment and depreciation. In other words, net farm income was computed using:

$$
\mathrm{NFI}=\sum_{i=1}^{n} \text { Gross Margin }_{i}-\text { Total Fixed Cost }{ }_{i}
$$

Finally, return on asset/investment was computed to ascertain the profitability or the effectiveness in producing profit from capital invested by smallholder cocoyam producers in the study districts. Kohl and Wilson [21] defined return on investment (ROI) as a ratio of net farm income or profit adjusted by interest expenses and opportunity cost for unpaid labour and management relative to the average cost of assets as specified in Eq. 4.

$$
\begin{aligned}
& \text { Rate of return on investment (ROI) } \\
& =\sum_{i=1}^{n} \frac{\text { Returns to assets }}{\text { Average total assets }} \%
\end{aligned}
$$

Returns to asset were computed as the net farm income less the value of operator labour and management. Slight modifications were done in estimating the returns to assets. The adjustment for loan interest was not necessary here because small-scale cocoyam producers financed their production through own equity.

Owner inputs like farmers' own corm setts used for planting and any other input which was not directly purchased by farmer as well as family labour and management were valued based on prevailing market prices. Furthermore, all standard production costs used for estimations and generating income statements were based on the average fair market value of the cost items for the $2014 / 2015$ cropping season. Income statements that were generated therefore represent the average cocoyam farm 
per district or per cropping system. Given the reality of complexity in determining the level of resource use when dealing with one crop within an intercropping system, estimations and apportioning of labour, land and other resources were done solely based on the proportion of land that was covered by cocoyam. Following the principles of evaluation of farm systems by McConnel and Dilson [22], further analysis of returns to land and operator labour and management is conducted using Eqs. 5 and 6.

$$
\begin{aligned}
& \text { Return to labour and mgt } \\
& \quad=\text { NFI - Opportunity cost of capital }
\end{aligned}
$$

$$
\text { Return to land = NFI }- \text { opp cost of capital less land }
$$

$$
\text { - opp cost of labour and mgt }
$$

The opportunity cost of capital was estimated using the prevailing cost of capital in the economy, i.e. $25 \%$ according to the Bank of Ghana [23]. Similarly, all exchange rates quoted in the results for comparative understanding refer to the average nominal exchange rate as at the end of the 2015 financial year (December 2015), and it was also sourced from the Bank of Ghana [23]. Analysis focussed on the return to family labour and management of producers instead of the disaggregated returns on labour and returns on management. This was because cocoyam production is typically a small-scale agricultural enterprise and management is so closely interlinked with family labour. Therefore, distinguishing between family labour and management in the case of small farms is practically difficult to do [22].

Analysis was performed at the district, cropping systems and pooled levels. The ANOVA tests were conducted on selected variables to highlight significant differences or otherwise of such variables across the study districts. Where the $F$-statistic was found to be significant, Tukey HSD post hoc tests were conducted on all possible pairwise contrasts. Student's $T$ test was used to test mean differences of selected variables at cropping system-level analysis. Critical production and socioeconomic characteristics of cocoyam producers such as cocoyam farm size, farming experience, total cultivated land among others were tested for significant differences in order to justify the suitability of data aggregation. Based on this, pooling of the data was considered appropriate and statistically acceptable. An intuitive approach was adopted in the allocation of cost of labour and other inputs under the intercropping system. Unlike the specific activities such as planting, harvesting, gathering and transportation whose associated costs were direct, shared costs such as land preparation, weeding, spraying were imputed by the multiplying the associated costs by the proportion of the total farm area which was covered by cocoyam alone.

\section{Results and discussion}

\section{Descriptive results}

Table 2 shows the demographic and other farm-level characteristics of cocoyam producers. Women farmers dominated cocoyam cultivation (56\%). Similar pattern was observed across the districts except Fanteakwa where $78 \%$ of the respondents were male, in keeping with the findings of Quaye et al. [5]. Generally, the results resonate with the assertion that cocoyam production is a considered reserve of women farmers [1, 24, 25].

On the other hand, the higher involvement of men in cocoyam production in the Fanteakwa district could be attributed to the higher commercial value associated with cocoyam within the district as posited by Talwana et al. [6]. Unlike male farmers in Asunafo North and Asante Akyem South who are exposed to cultivation of cash crops like cocoa and hence leave the cultivation of cocoyam to females, male farmers in Fanteakwa mainly cultivate cocoyam as a major cash crop and hence their significant involvement relative to the other producing districts.

Majority (54\%) of the farmers produced cocoyam on own lands. These producers obtained their ownership rights either through outright purchase or by inheritance. On the other hand, approximately $12 \%$ of them produced cocoyam on rented farmlands, while $11 \%$ cultivated cocoyam on family or stool lands. Farmers who cultivated cocoyam on stool or family lands, rented lands and sharecropped lands had restricted control over such lands unlike their counterparts who owned their lands. Some farmers from the Fanteakwa district had special but controlled access to certain lands and secondary forest reserves under government supervision. This represented $10 \%$ of the total land ownership status from the district. Aside that, $22 \%$ of the cocoyam producers from the district were using rented farmlands to grow cocoyam. This highlights the apparent scarcity of land for cocoyam cultivation in the Fanteakwa compared to the other districts. About $42 \%$ of producers from the Fanteakwa district were farming on own lands. Apart from cocoyam producers in Fanteakwa, farmers who usually used rented lands for cocoyam production primarily did so for cocoa production. Cocoyam and plantains were then used as shade crops for the cocoa plants until the latter formed its own canopy.

Intercropping was the commonest cropping culture for cocoyam $(84 \%)$. This cropping pattern was consistent among all the districts; however, a relatively higher number of farmers in Fanteakwa (22\%) cultivated the root crop on sole crop basis compared to $20 \%$ and only $6 \%$ for Asunafo North and Asante Akyem South, respectively. Cocoyam was predominantly intercropped with plantain, cassava and cocoa. The results partially agree with the 
Table 2 Demographic and farm-level characteristics of cocoyam producers by district

\begin{tabular}{|c|c|c|c|c|c|c|c|c|}
\hline \multirow[t]{2}{*}{ Variable } & \multicolumn{2}{|c|}{ Asante Akyem South } & \multicolumn{2}{|c|}{ Asunafo North } & \multicolumn{2}{|c|}{ Fanteakwa } & \multicolumn{2}{|c|}{ Pooled } \\
\hline & Freq & $\%$ & Freq & $\%$ & Freq & $\%$ & Freq & $\%$ \\
\hline \multicolumn{9}{|l|}{ Gender } \\
\hline Male & 21 & 42 & 25 & 50 & 38 & 78 & 66 & 44 \\
\hline Female & 29 & 58 & 25 & 50 & 12 & 24 & 84 & 56 \\
\hline \multicolumn{9}{|l|}{ Educational status } \\
\hline None & 4 & 8 & 20 & 40 & 14 & 28 & 38 & 25.3 \\
\hline Basic/non-formal & 43 & 86 & 29 & 58 & 28 & 56 & 100 & 66.7 \\
\hline Secondary/pre-tertiary & 3 & 6 & 1 & 2 & 8 & 16 & 12 & 8 \\
\hline \multicolumn{9}{|l|}{ Land occupancy status } \\
\hline Own land/inherited & 31 & 62 & 29 & 58 & 21 & 42 & 81 & 54 \\
\hline Family/stool land & 7 & 14 & 5 & 10 & 6 & 12 & 18 & 12 \\
\hline Rented & 6 & 12 & - & & 11 & 22 & 17 & 11.3 \\
\hline Sharecropping & 6 & 12 & 16 & 32 & 7 & 14 & 29 & 19.3 \\
\hline Other (government lands, forest reserves) & - & & - & & 5 & 10 & 5 & 3.3 \\
\hline \multicolumn{9}{|l|}{ Cropping culture practised } \\
\hline Sole cropping & 3 & 6 & 10 & 20 & 11 & 22 & 24 & 16 \\
\hline Intercropping & 47 & 94 & 40 & 80 & 39 & 78 & 126 & 84 \\
\hline \multicolumn{9}{|l|}{ Main reason for growing cocoyam } \\
\hline Household consumption only & 1 & 2 & 10 & 20 & 1 & 2 & 12 & 8 \\
\hline Mainly for household consumption, sell surplus & 1 & 2 & 9 & 18 & 3 & 6 & 13 & 8.7 \\
\hline Equally for sale and household consumption & 30 & 60 & 23 & 46 & 23 & 46 & 76 & 50.7 \\
\hline Mainly for sale & 18 & 36 & 8 & 16 & 23 & 46 & 49 & 32.7 \\
\hline \multicolumn{9}{|l|}{ Target produce for sale } \\
\hline Corms only & 26 & 53.1 & 27 & 67.5 & 39 & 79.6 & 93 & 67.4 \\
\hline Both leaves and corms & 23 & 46.9 & 13 & 32.5 & 10 & 20.4 & 45 & 32.6 \\
\hline Leaves only & - & & - & & - & & - & \\
\hline \multicolumn{9}{|l|}{ Major labour sources } \\
\hline Family labour & 33 & 66 & 46 & 92 & 42 & 84 & 121 & 80.6 \\
\hline Hired labour & 17 & 34 & 4 & 8 & 8 & 16 & 29 & 19.4 \\
\hline \multicolumn{9}{|c|}{$N($ Pooled $)=150 ; N($ AAS $)=50 ; N($ AN_D $)=50 ; N($ F_D $)=50$} \\
\hline
\end{tabular}

AAS Asante Akyem South, AN_D Asunafo North, $F \_D$ Fanteakwa

* Total $N$ for 'target produce for sale' does not include producers who cultivate for consumption only

findings of Quaye et al. [5] who concluded that cocoyam is cultivated mainly as an intercrop. However, they did not report any findings on sole cropping of cocoyam. Only $8 \%$ cultivated cocoyam solely for subsistence with majority, indicating that they cultivated cocoyam equally for household consumption and sale. The main economic part targeted for sale was the cormels but interestingly, none of the respondents cultivated cocoyam solely for its leaves, and this can be largely attributed to the objective of production. These results imply that farmers produce cocoyam with the dual objective of ensuring household and income security of producing households.

The result affirms the argument of Ajijola [17] that cocoyam production constitutes a significant component of food production as well as income generation of producing households. Table 2 also reveals that producers predominantly relied on family labour as their main source of labour (80.6\%) probably to reduce cost of production and to control for labour scarcity. Averagely, a cocoyam farmer was about 48 years old as listed in Table 3. The mean age of 48 years implies that respondents are active and more likely to make use of agricultural innovation and technologies [26, 27]. Generally, the average cocoyam farmer had completed the basic level of formal education. The result suggests a fair level of literacy since farmers at that level can read and write to some extent. Good literacy rate of farmers is known to facilitate innovation, a technology adoption and transfer [27]. Cocoyam farming household constituted an average of seven members with a mean of 15 years in cocoyam farming. This suggests that, all things equal, respondents have access to household 
Table 3 Descriptive statistics of socio-economic characteristics of cocoyam producers

\begin{tabular}{|c|c|c|c|c|c|c|c|}
\hline Variable & District & Minimum & Maximum & Mean & SD & $\mathrm{CV}(\%)^{\mathrm{a}}$ & Test statistic $F(2,147)$ \\
\hline \multirow[t]{4}{*}{ Age (years) } & AAS & 20 & 67 & 44.86 & 9.83 & 21.91 & $3.10^{* *}$ \\
\hline & AN_D & 22 & 73 & 49.24 & 13.59 & 27.6 & \\
\hline & F_D & 30 & 70 & 50.24 & 9.78 & 19.47 & \\
\hline & Pooled & 20 & 73 & 48 & 11.5 & 23.96 & \\
\hline \multirow[t]{4}{*}{ Years in formal education } & AAS & 4 & 15 & 9.20 & 2.57 & 27.93 & 2.57 \\
\hline & AN_D & 2 & 12 & 8.07 & 2.73 & 33.83 & \\
\hline & F_D & 3 & 15 & 9.34 & 2.76 & 29.55 & \\
\hline & Pooled & 2 & 15 & 8.92 & 2.71 & 30.38 & \\
\hline \multirow[t]{4}{*}{ Household size } & AAS & 1 & 12 & 6.04 & 2.43 & 40.23 & 2.93 \\
\hline & AN_D & 1 & 15 & 6.67 & 3.52 & 52.77 & \\
\hline & F_D & 1 & 20 & 7.73 & 2.65 & 34.28 & \\
\hline & Pooled & 1 & 20 & 6.85 & 3.01 & 43.94 & \\
\hline \multirow[t]{4}{*}{ Cocoyam farm size (hectares) } & AAS & 0.25 & 0.59 & 0.38 & 0.14 & 36.84 & 2.61 \\
\hline & AN_D & 0.36 & 1.1 & 0.77 & 0.29 & 37.66 & \\
\hline & F_D & 0.39 & 1.5 & 0.84 & 0.38 & 45.24 & \\
\hline & Pooled & 0.25 & 1.5 & 0.55 & 0.21 & 38.18 & \\
\hline \multirow[t]{4}{*}{ Total agricultural land (hectares) } & AAS & 0.61 & 8.10 & 3.23 & 1.68 & 52.01 & 2.56 \\
\hline & AN_D & 0.53 & 8.91 & 4.49 & 3.20 & 66.81 & \\
\hline & F_D & 0.81 & 12.15 & 4.79 & 2.59 & 54.07 & \\
\hline & Pooled & 0.53 & 12.15 & 4.17 & 2.62 & 62.83 & \\
\hline \multirow[t]{4}{*}{ Total cultivated land (hectares) } & AAS & 0.61 & 4.05 & 2.09 & 1.49 & 71.29 & 1.92 \\
\hline & AN_D & 0.53 & 8.10 & 3.48 & 2.60 & 74.71 & \\
\hline & F_D & 0.81 & 10.12 & 3.37 & 2.91 & 86.35 & \\
\hline & Pooled & 0.53 & 10.12 & 2.98 & 2.17 & 72.82 & \\
\hline \multirow[t]{4}{*}{ Cocoyam farming experience (years) } & AAS & 2 & 30 & 9.57 & 8.24 & 86.1 & 2.40 \\
\hline & AN_D & 2 & 53 & 16.69 & 13 & 77.89 & \\
\hline & $F_{-} D$ & 2 & 50 & 19.76 & 11.40 & 57.69 & \\
\hline & Pooled & 2 & 53 & 15.31 & 11.84 & 77.34 & \\
\hline
\end{tabular}

AAS Asante Akyem South, AN_D Asunafo North, F_D Fanteakwa

** $p<0.05$

a Coefficient of variation (CV) is a measure of relative dispersion calculated by expressing standard deviation (SD) as a percentage of the mean $(X)$, i.e. $C V=S D / \bar{X}$

labour, thereby reducing the operational cost of production as indicated by Adepoju and Awondunmuyila [16].

Furthermore, the total agricultural land controlled by producers averaged 4.17 hectares. Cocoyam producers in Fanteakwa cultivated more acreages compared to their counterparts from Asante Akyem South and Asunafo North districts. The typical farmer cultivated about 3 hectares of land out of which 0.55 hectares was allotted for cocoyam cultivation. This represented about 18.5\% of total cultivated land and 13\% of total agricultural land controlled by cocoyam farmers, confirming that cocoyam cultivation was generally done on a small scale.

From the ANOVA test results, farmer's age across the districts yielded a statistically significant difference $[F(2$, $147)=3.1, p=0.48]$. A Tukey post hoc test revealed that the mean age of cocoyam producers in the Asante Akyem district $(M=44.9, \mathrm{SD}=9.8)$ was significantly lower than those in Fanteakwa $(M=50.2, \mathrm{SD}=9.9)$ at $5 \%$ significance level. No significant difference was observed between the mean ages of Asante Akyem and Asunafo North farmers as well as between Asunafo North and Fanteakwa farmers. Pointedly, all other descriptive socioeconomic and production characteristics of cocoyam producers were not significantly different across the three districts at $5 \%$ significance level. This gives an indication that these producers are largely homogenous across the districts.

\section{Profitability of cocoyam production}

Table 4 shows a summary of per hectare analysis of costs incurred by cocoyam farmers disaggregated into districts for purpose of emphasis. 
The total variable and fixed costs incurred by the average producer were GHC 3027 and GHC 340, respectively, per hectare of cocoyam production. Total cost of production per hectare of cocoyam was relatively higher in Fanteakwa (GH\& 3698) than in Asunafo North (GHc 3263) and Asante Akyem South (GHc 3120). This may probably be due to the scale and intensity of production within the respective districts. Total labour cost per hectare formed about 60 and $54 \%$ of the total variable cost and total production cost, respectively, making it the single most important cost component of cocoyam production. This result favourably compares with the findings of Quaye et al. [5] and Okoye et al. [18] that the cost of labour alone constitutes more than half of the total variable cost incurred in a cocoyam production enterprise. Producers spent slightly higher on labour in Asunafo North compared to total labour cost for their counterparts in Asante Akyem South and Fanteakwa in decreasing order. Weeding and harvesting were cited as the most labour-intensive activity for cocoyam. Cocoyam farmers in Fanteakwa incurred relatively higher marketing cost owing to the cost of transportation. Harvested cocoyam was mostly sold in the major market centres. These major market centres (Ashaiman, Agbogbloshie and Kasoa) are in the country's capital-Accra-which is about $125 \mathrm{~km}$ away from the district capital, Begoro. Table 5 shows the analysis on revenue per hectare of cocoyam production by districts.
Averagely, the total revenue accrued from both corms and leaves harvested for the production season was GHC 8191 per hectare. However, total or gross revenue per hectare of cocoyam production was highest in Fanteakwa with an average of GHc 9442, whereas producers in Asante Akyem South and Asunafo North recorded an average of GHC 7327 and GHC 7895 as total gross proceeds. Proceeds from the sale of cocoyam leaves constituted about $11 \%$ of the total revenue received by farmers with farmers in Asante Akyem South obtaining the highest contribution (17\%) of leaves to cocoyam revenue, suggesting that revenue from the sale of cocoyam contributes significantly to the profitability and overall income from cocoyam. Farmers in Fanteakwa obtained the highest revenue and margin basically because of the yield and relatively better produce price of $\mathrm{GH} 41.1$ per kilogram compared to $\mathrm{GH} 0.9$ and $\mathrm{GH} 0.8$ per kilogram of corm obtained by farmers in Asante Akyem South and Asunafo North, respectively. Sagoe et al. [13] found out that the gross farm gate benefits of cocoyam was GHC 2090 per hectare for corms proceeds only. This could indicate that revenue from cocoyam enterprise has increased over the years as a result of good produce prices. Again, Sagoe et al. [13] did not include contribution of leaves to total revenue per hectare of production; therefore, possibilities of understatement of benefits may arise. The average cocoyam farmer earned GH4 4824 as net income per hectare with Fanteakwa farmers benefiting most from cocoyam production.

Table 4 Cost analysis on cocoyam production (hectare) by districts

\begin{tabular}{|c|c|c|c|c|c|c|}
\hline \multirow[t]{2}{*}{ Cost item } & \multicolumn{4}{|c|}{ Average value (GHC)); GHc $1.00=$ USD $0.29(B o G, 2016)$} & \multirow{2}{*}{$\begin{array}{l}\text { \% share of TVC } \\
\text { (pooled) }\end{array}$} & \multirow{2}{*}{$\begin{array}{l}\text { \% share of TC } \\
\text { (pooled) }\end{array}$} \\
\hline & Asante Akyem & Asunafo North & Fanteakwa & Pooled & & \\
\hline \multicolumn{7}{|l|}{ Variable cost } \\
\hline Total labour cost & 1815 & 1825 & 1812 & 1818 & 60 & 54 \\
\hline Corm setts & 210 & 300 & 250 & 243 & 8 & 7 \\
\hline Herbicide & 107 & 142 & 101 & 108 & 9 & 8 \\
\hline Fertiliser & 214 & 355 & 189 & 261 & 3 & 3 \\
\hline \multicolumn{7}{|l|}{ Marketing costs } \\
\hline Loading and offloading & 51 & 64 & 61 & 57 & & \\
\hline Market tolls/tickets & 49 & 50 & 60 & 52 & & \\
\hline Carriage/transportation & 306 & 274 & 826 & 488 & & \\
\hline Total marketing cost & 406 & 388 & 947 & 597 & 20 & 18 \\
\hline Total variable cost ${ }^{A}$ & 2752 & 3010 & 3299 & 3027 & & \\
\hline \multicolumn{7}{|l|}{ Fixed costs } \\
\hline Land rent & 207 & 104 & 225 & 180 & & 5 \\
\hline Farm assets (cutlass, sacks, baskets) & 135 & 118 & 135 & 127 & & 4 \\
\hline Depreciation (hoes, sprayers) & 26 & 31 & 39 & 33 & & 1 \\
\hline Total fixed cost ${ }^{B}$ & 368 & 253 & 399 & 340 & & \\
\hline Total $\operatorname{cost}^{C}(A+B)$ & 3120 & 3263 & 3698 & 3367 & & \\
\hline
\end{tabular}


Table 5 Returns analysis of cocoyam production (hectare) by districts

\begin{tabular}{|c|c|c|c|c|}
\hline \multirow[t]{2}{*}{ Item } & \multicolumn{4}{|c|}{ Average value $(\mathrm{GHC}) ; \mathrm{GH} C 1.00=$ USD $0.29(\mathrm{BoG}, 2016)$} \\
\hline & Asante Akyem South & Asunafo North & Fanteakwa & Pooled \\
\hline \multicolumn{5}{|l|}{ Cocoyam output } \\
\hline Quantity of corms harvested (kg) & 6033 & 6623 & 6873 & 6515 \\
\hline Selling price per kg (corms) & 1.01 & 1.09 & 1.29 & 1.13 \\
\hline Quantity of leaves harvested (kg) & 881 & 483 & 411 & 592 \\
\hline Selling price per kg (leaves) & 1.4 & 1.4 & 1.4 & 1.4 \\
\hline \multicolumn{5}{|l|}{ Revenue (value of production) } \\
\hline Corms $^{\mathrm{D}}$ & 6093 & 7219 & 8866 & 7362 \\
\hline Leaves & 1233 & 676 & 575 & 829 \\
\hline Total returns ${ }^{\mathrm{E}}$ & 7327 & 7895 & 9442 & 8191 \\
\hline$\%$ contribution of leaves to total revenue & 17 & 9 & 6 & 11 \\
\hline Gross margin (D-A) (corm only) ${ }^{F}$ & 3341 & 4209 & 5567 & 4335 \\
\hline Gross margin $(E-A)^{G}$ & 4575 & 4885 & 6143 & 5164 \\
\hline Net income (D-C) (corm only) & 2973 & 3956 & 5168 & 3995 \\
\hline Net income (E-C) & 4207 & 4632 & 5744 & 4824 \\
\hline
\end{tabular}

\section{Return to assets, land and operator labour} and management in cocoyam production by district

Averagely, producers earned $24.1 \%$ on their farm assets per hectare of cocoyam farm. This implies that, all things being equal, for any GHC 1.00 invested into cocoyam production, producers earned about $\mathrm{GH} 40.24$ as profit. Covering about $95 \%$ of the total investment in farm assets for cocoyam production, land was the most expensive capital asset used by producers. Relative to similar agricultural enterprises, the return on investment for cocoyam production compares lower to crops like cassava and maize (40 and 43\%, respectively) [28, 29]. On the other hand, cocoyam has a higher ROI compared to plantain production (12.6\%) [30]. The consistent increase in acreages for crops like cocoa, cassava and maize coupled with these higher return on investment relative to cocoyam production suggests that farmers are shifting to the cultivation of the former and hence the decline in the latter because production of those crops (cocoa, cassava, yam, maize) is more competitive and profitable. Furthermore, ROI of $24 \%$ for cocoyam production compares lower than the prevailing cost of capital in Ghana, which stands at about $25 \%$ [23]. This implies that presently the alternative use of capital may be more economically sound than its use in cocoyam production. Therefore, cocoyam production is not financially attractive at the moment. This result disagrees with the findings of Azeez and Madukwe [2], Quaye et al. [5] and Sagoe et al. [13] who found cocoyam production to be generally profitable.

Disaggregated data on districts showed mixed results across districts with production in Fanteakwa being profitable with ROI of about $27.6 \%$. For every GH\& 1.00 invested into cocoyam production, farmers in Asante Akyem South earned about GHC 0.20 more as profit, while those in Asunafo North and Fanteakwa earned about GHC 0.25 and GHC 0.28 more, respectively. This result probably explains the scale, intensity of cocoyam production and why relatively more male farmers are involved in cocoyam production in Fanteakwa than the other districts. The differences in profitability across districts can also be linked to the differences in costs of doing business as well as produce prices (cormels) in respective districts.

Table 6 further shows that the return to agricultural lands committed to cocoyam production averaged $\mathrm{GHC}$ 980.3 per hectare. Interestingly, the return to land for farmers in Asunafo North was slightly lower (GHc 979) compared to the other districts. Competition for land for cash crop cultivation like cocoa has driven up the value of agricultural land in Asante Akyem and Asunafo North and hence a higher opportunity cost of land in these areas. Coupled with the relatively low yield of cocoyam, the returns to land in these areas compare lower to that of Fanteakwa. Compared with prevailing rent (per hectare) of GHC 180 cocoyam, farmers are better of cultivating cocoyam than if they had rented out their lands. This result emphasises the significance of land to the profitability of cocoyam production. Furthermore, farmers earned an average of GHC 3696.3 for the 2014/2015 cropping season as return to family labour and management after subtracting the opportunity cost of capital (25\% of the total cost of capital). As expected, producers in Fanteakwa earned significantly high returns on farmer's labour and management (GHc 4715.7) than those in 
Table 6 Return on assets, land and labour management for cocoyam production (per hectare)

\begin{tabular}{|c|c|c|c|c|}
\hline \multirow[t]{2}{*}{ Farm assets } & \multicolumn{4}{|c|}{ Value of assets (GHC) used per ha of cocoyam production $(2014 / 2015)$} \\
\hline & Asante Akyem South & Asunafo North & Fanteakwa & Pooled \\
\hline Land & 4990 & 4002 & 3861 & 4284 \\
\hline \multicolumn{5}{|l|}{ Equipment and machinery } \\
\hline Cutlass & 44 & 38 & 37 & 37.7 \\
\hline Sacks & 25.2 & 30 & 40.8 & 34 \\
\hline Baskets/pans & 66 & 50 & 57.5 & 55 \\
\hline Hoes & 28.6 & 24 & 38 & 30 \\
\hline Sprayer & 50 & 70 & 79 & 70 \\
\hline Total assets/investment ${ }^{A}$ & 5203.8 & 4214 & 4113.3 & 4510.7 \\
\hline \multicolumn{5}{|l|}{ Analysis of return on key resources } \\
\hline Net farm profit ${ }^{B}$ & 4207 & 4632 & 5744 & 4824 \\
\hline Interest expenses & - & - & - & - \\
\hline Value of unpaid labour and management ${ }^{C *}$ & 3150 & 3600 & 4610 & 3787 \\
\hline Return to assets $(A-B)^{D}$ & 1075 & 1032 & 1134 & 1037 \\
\hline Rate of return on investment (ROI) (D/A) \% & 20.3 & 24.5 & 27.6 & 24.1 \\
\hline Opportunity cost of capital (at 25\%) & 1301 & 1053.5 & 1028.3 & 1127.7 \\
\hline Total capital less land & 213.8 & 212 & 252.3 & 226.7 \\
\hline Opportunity cost of capital less land & 53.5 & 53 & 63 & 56 \\
\hline Return to land & 1003.6 & 979 & 1070.9 & 980.3 \\
\hline Return to unpaid labour and mgt & 2906.1 & 3578.5 & 4715.7 & 3696.3 \\
\hline Return to per unit (day) unpaid labour and mgt & 20.8 & 23.9 & 29.5 & 24.6 \\
\hline
\end{tabular}

* Values represent the opportunity costs for operator (household) labour and management on cocoyam farms for the various producing districts GHC $1.00=$ USD 0.29 (BoG, 2016)

Asunafo North (GH\& 3578.5), whereas farmers in Asante Akyem South earned GH\& 2906.1 as returns to their own labour and management for the period. This implies that farmers averagely earned GH\$ 24.6 per day as returns to labour and management ability.

Compared to the average wage rate of $\mathrm{GHC} 13$ and the prevailing minimum wage rate of GH\& 7 [23], farmers earned more on their efforts than they would have if they had worked as farm hands on other or off-farm enterprises. McConnell and Dillon [22] stated that it is practically difficult to distinguish management ability from farmer's labour in smallholder agricultural enterprises. Therefore, the estimated returns to labour and management are naturally expected to be higher than the prevailing wage rates. This is so because wage rates provide information on the opportunity cost of labour excluding management ability. It is observed largely that the returns to key resources, i.e. capital (asset), land and labour and management were highest at locations with relatively lower cost of labour and where the use of agrochemicals was low. This highlights the importance of labour and agrochemicals usage to the profitability of cocoyam enterprises. Table 7 presents a summary of the statistical differences between the key variables discussed so far.
Total cost of production per hectare of cocoyam did not differ significantly across the three districts at $5 \%$ significance level. This is indicative of the fact that cultivation methods and practises for cocoyam producers in the three districts were virtually similar-the use of indigenous planting materials; minimal application of chemicals and soil enhancers; and high labour input. However, per hectare gross margin $[F(2,147)=6.26]$, net income $[F(2,147)=4.89]$, return on assets $[F(2,147)=3.37]$, returns to land $[F(2,147)=3.36]$ and returns to unpaid labour and management $[F(2,147)=4.19]$ yielded statistically significant variation across the districts. Specifically, the Tukey HSD test reveal that the mean gross margin of Fanteakwa cocoyam producers was significantly higher than farmers in Asunafo North and Asante Akyem South with mean differences (MD) of -1258 and 1569, respectively. Margins gained by farmers in Asunafo North and Asante Akyem South did not yield any significant variation $(\mathrm{MD}=-311)$ implying similar gross margins per hectare of cocoyam for the two districts.

The significant difference in total net income across districts is also explained by the fact that Fanteakwa farmers gained significantly higher net income than their counterparts, whereas no significant variation in net incomes was observed between Asunafo North and 
Table 7 ANOVA and Tukey HSD test results for selected variables (by district)

\begin{tabular}{|c|c|c|c|c|c|}
\hline Variable & District & Mean per ha & SD & $\begin{array}{l}F \text {-statistic } \\
F(2,147)\end{array}$ & $\begin{array}{l}\text { Tukey HSD post hoc } \\
\text { Mean difference (MD) }\end{array}$ \\
\hline \multirow[t]{3}{*}{ Yield per ha (corms + leaves) } & AAS & 6914 & 7291.71 & $3.53^{* *}$ & btwn (AAS \&AN_D) $=-192^{* *}$ \\
\hline & AN_D & 7106 & 6502.23 & & btwn (AN_D\&F_D) $=-178^{* *}$ \\
\hline & F_D & 7284 & 6164.09 & & btwn $\left(F \_D \& A A S\right)=370^{* *}$ \\
\hline \multirow[t]{3}{*}{ Produce price per kg } & AAS & 2.41 & 1.53 & $5.59^{* *}$ & btwn (AAS \& AN_D) $=-0.08$ \\
\hline & AN_D & 2.49 & 1.12 & & btwn (AN_D\&F_D) $=-0.04^{* *}$ \\
\hline & F_D & 2.53 & 1.76 & & $\operatorname{btwn}\left(F \_D \& A A S\right)=0.12^{* *}$ \\
\hline \multirow[t]{3}{*}{ Total production cost } & AAS & 3120 & 1103.18 & 1.12 & \\
\hline & AN_D & 3262 & 1606.28 & & \\
\hline & F_D & 3698 & 1916.95 & & \\
\hline \multirow[t]{3}{*}{ Gross margin } & AAS & 4574 & 4795.29 & $6.26^{* *}$ & btwn (AAS \& AN_D) $=-311$ \\
\hline & AN_D & 4885 & 3850.38 & & btwn (AN_D\&F_D) $=-1258^{* *}$ \\
\hline & F_D & 6143 & 5650.47 & & $\operatorname{btwn}\left(F_{-} D \& A A S\right)=1569^{* *}$ \\
\hline \multirow[t]{3}{*}{ Net income (corm only) } & AAS & 2973 & 2965.98 & $5.08^{* *}$ & btwn (AAS \& AN_D) $=-983^{* *}$ \\
\hline & AN_D & 3956 & 3302.75 & & btwn (AN_D\&F_D) $=-1212^{* *}$ \\
\hline & F_D & 5168 & 5626.17 & & $\operatorname{btwn}\left(F_{-} D \& A A S\right)=2195^{* *}$ \\
\hline \multirow{3}{*}{ Total net income (corm + leaves) } & AAS & 4207 & 3836.25 & $4.89^{* *}$ & btwn (AAS \& AN_D) $=-425$ \\
\hline & AN_D & 4632 & 4597.31 & & $\operatorname{btwn}\left(A N \_D \& F \_D\right)=-1112^{* *}$ \\
\hline & F_D & 5744 & 5063.74 & & $\operatorname{btwn}\left(F_{-} D \& A A S\right)=1537^{* *}$ \\
\hline \multirow[t]{3}{*}{ Return on assets } & AAS & 20.3 & 12.6 & $3.37^{* *}$ & btwn (AAS \& AN_D) $=-4.2^{* *}$ \\
\hline & AN_D & 24.5 & 21.3 & & btwn (AN_D \& F_D) $=-3.1^{* *}$ \\
\hline & F_D & 27.6 & 15.5 & & btwn $\left(F \_D \& A A S\right)=7.3^{* *}$ \\
\hline \multirow[t]{3}{*}{ Returns to land } & AAS & 1003.6 & 567.99 & $3.86^{* *}$ & btwn (AAS \& AN_D) $=-4.2^{* *}$ \\
\hline & AN_D & 979 & 535.53 & & btwn (AN_D \& F_D) $=-3.1^{* *}$ \\
\hline & F_D & 1070.9 & 602.25 & & $\operatorname{btwn}\left(F \_D \& A A S\right)=7.3^{* *}$ \\
\hline \multirow[t]{3}{*}{ Return to unpaid labour and mgt } & AAS & 2906.1 & 2587.72 & $4.19 * *$ & btwn (AAS \&AN_D) $=-672.4^{* *}$ \\
\hline & AN_D & 3578.5 & 2699.91 & & btwn (AN_D\&F_D) $=-1137.2$ \\
\hline & $F_{-} D$ & 4715.7 & 3143.12 & & btwn $\left(F \_D \& A A S\right)=1809.6^{* *}$ \\
\hline
\end{tabular}

** Significant scores at 5\% significance level

Asante Akyem South farmers. Returns on assets and returns to land for cocoyam producers in Fanteakwa were found to be significantly higher than producers in the other two districts, whereas production in Asunafo North also yielded significantly higher ROA and returns to land than those in Asante Akyem South. As expected, the returns to unpaid labour for Fanteakwa farmers were significantly higher than for the other districts. However, the post hoc test also reveals that the returns to own labour and management were not statistically significant between producers in Asunafo North and Fanteakwa districts.

For the purpose of emphasis, it can be seen from Table 7 that, at 5\% significance level, cocoyam yield was significantly higher in Fanteakwa than the two districts and also significantly higher in Asunafo North than in Asante Akyem South. Interestingly, produce price per $\mathrm{kg}$ was not found to be significantly different in Asunafo North and Asante Akyem South though a significantly higher market price is observed in favour of Fanteakwa producers. As earlier on indicated, these results confirm that Fanteakwa farmers are better off than their counterparts mainly due to the relatively higher yield and market price per $\mathrm{kg}$ of produce. On the other hand, cocoyam farmers in the Asunafo North district earn more from cocoyam than those in Asante Akyem South mainly due to relatively higher output per hectare of cocoyam cultivated.

\section{Cost and returns analysis of cocoyam production by cropping system}

Generally, total labour cost under the sole cropping system is higher than under the intercropping system, signifying that cocoyam cultivated as a sole crop is relatively more labour-intensive than when intercropped (Table 8). Labour cost was affected mainly by number of man-days used for carrying out activities like weeding, spraying and harvesting which is carried out manually. Such cultural practices under sole crop cocoyam require a lot of care by farmhands, especially because of the tender stems of the 
Table 8 Cost analysis on cocoyam production (hectare) by cropping system

\begin{tabular}{|c|c|c|c|}
\hline \multirow[t]{2}{*}{ Cost item } & \multicolumn{3}{|c|}{$\begin{array}{l}\text { Average value }(\mathrm{GH} C) ; \mathrm{GHC} 1.00=\text { USD } \\
0.29\end{array}$} \\
\hline & Sole cropping & Intercropping & Pooled \\
\hline \multicolumn{4}{|l|}{ Variable cost } \\
\hline Total labour cost & 1850 & 1726 & 1818 \\
\hline Corm setts & 300 & 225 & 243 \\
\hline Herbicide & 77 & 112 & 108 \\
\hline Fertiliser & 203 & 405 & 261 \\
\hline \multicolumn{4}{|l|}{ Marketing costs } \\
\hline Loading and offloading & 102 & 55 & 57 \\
\hline Market tolls/tickets & 60 & 50 & 52 \\
\hline Carriage/transportation & 560 & 475 & 488 \\
\hline Total marketing cost & 722 & 582 & 597 \\
\hline Total variable $\operatorname{cost}^{\mathrm{A}}$ & 3152 & 3001 & 3027 \\
\hline \multicolumn{4}{|l|}{ Fixed costs } \\
\hline Land rent & 158 & 202 & 180 \\
\hline $\begin{array}{l}\text { Farm assets (cutlass, sacks, } \\
\text { baskets) }\end{array}$ & 128 & 108 & 127 \\
\hline Depreciation (hoes, sprayers) & 31 & 34 & 33 \\
\hline Total fixed $\operatorname{cost}^{\mathrm{B}}$ & 317 & 344 & 340 \\
\hline Total cost $(A+B)$ & 3469 & 3345 & 3367 \\
\hline
\end{tabular}

root crop and the crops sensitivity to chemicals, thereby increasing the man hours required to complete a task. Therefore, per the intuitive of approach of apportioning shared costs based on the area covered by cocoyam, the labour costs under the intercropping system were lower because labour was less intensive under this system.

Noticeably, producers spent more on agrochemicals under the intercropping system than farmers who cultivated cocoyam on sole crop basis. This is so because cocoyam sole croppers were quite reserved at applying chemicals to cocoyam due to the perception that herbicides caused plants to wither and die while applying fertiliser reduced the storability of the corms. However, relatively more was spent on agrochemicals under the intercropping system due to the fact that cocoyam was often not the main crop and that the main crops required agrochemicals to be applied to enhance its yield.

Generally, production cost was higher (GHd 3469) under the sole cropping system than under the intercropping system (GHC 3345) obviously owing to the differences in production intensity. However, this apparent difference in production cost was not statistically significant across cropping systems $(\mathrm{T}$ score $=2.06$; Table 11). As listed in Table 9, producers benefited more from cocoyam leaves under the intercropping system than under the sole cropping system. About $13.4 \%$ of the
Table 9 Returns analysis of cocoyam production (hectare) by cropping systems

\begin{tabular}{|c|c|c|c|}
\hline \multirow[t]{2}{*}{ Item } & \multicolumn{3}{|c|}{$\begin{array}{l}\text { Average value }(\mathrm{GHC}) ; \mathrm{GH} C 1.00=\text { USD } \\
0.29\end{array}$} \\
\hline & Sole cropping & Intercropping & Pooled \\
\hline \multicolumn{4}{|l|}{ Cocoyam output } \\
\hline $\begin{array}{l}\text { Quantity of corms harvested } \\
(\mathrm{kg})\end{array}$ & 7042 & 5985 & 6515 \\
\hline Selling price per kg (corms) & 1.13 & 1.13 & 1.13 \\
\hline $\begin{array}{l}\text { Quantity of leaves harvested } \\
\text { (kg) }\end{array}$ & 439 & 746 & 592 \\
\hline Selling price per kg (leaves) & 1.4 & 1.4 & 1.4 \\
\hline \multicolumn{4}{|l|}{ Revenue } \\
\hline Corms $^{\mathrm{D}}$ & 7957.5 & 6763.1 & 7362 \\
\hline Leaves & 615 & 1044 & 829 \\
\hline Total returns ${ }^{E}$ & 8572.5 & 7807.1 & 8191 \\
\hline $\begin{array}{l}\% \text { contribution of leaves to } \\
\text { total revenue }\end{array}$ & 7.1 & 13.4 & 11 \\
\hline $\begin{array}{l}\text { Gross margin (D-A) (corm } \\
\text { only) }\end{array}$ & 4805.5 & 3762.1 & 4335 \\
\hline Gross margin $(E-A)^{G}$ & 5420.5 & 4806.1 & 5164 \\
\hline $\begin{array}{l}\text { Net income (D-C) (corm } \\
\text { only) }\end{array}$ & 4876 & 3463 & 3995 \\
\hline Net income (E-C) & 5103.5 & 4462.1 & 4824 \\
\hline
\end{tabular}

revenue obtained from cocoyam production could be attributed to revenue from leaves under the intercropping system. About $7 \%$ of the revenue received by monocroppers could be attributed to revenue from cocoyam leaves. The reason was being that sole croppers usually cultivated cocoyam for its cormels. Therefore, such farmers harvest little to no cocoyam leaves at all for fear of reducing corm yield and hence the low yield of leaves under this cropping system.

The net income for cultivating cocoyam as a sole crop was GH\& 5103.5 and GH\$ 4462.1 when intercropped, and the observed difference was statistically significant at $5 \%$ significance level (Table 11). Summarily, the results agree with Sagoe et al. [13] who found that, given the two cropping systems, it was more profitable to cultivate cocoyam as a sole crop than as an intercrop when land is available.

\section{Return to assets, land and operator labour and management in cocoyam production by cropping system}

As already identified, the most significant set of resources employed in cocoyam production comprises of the classical triad of capital, land and labour. Table 10 shows the returns on assets, land and operator labour and management per hectare of cocoyam production under the two cropping systems. 
Table 10 Return on assets, land and labour management per cropping system (per hectare)

\begin{tabular}{|c|c|c|c|}
\hline \multirow[t]{2}{*}{ Farm assets } & \multicolumn{3}{|c|}{$\begin{array}{l}\text { Value of assets (GHC) used per ha } \\
\text { of cocoyam production (2014/2015) }\end{array}$} \\
\hline & Sole cropping & Intercropping & Pooled \\
\hline Land & 4284 & 4284 & 4284 \\
\hline \multicolumn{4}{|l|}{ Equipment and machinery } \\
\hline Cutlass & 37.7 & 37.7 & 37.7 \\
\hline Sacks & 34 & 34 & 34 \\
\hline Baskets & 55 & 55 & 55 \\
\hline Hoes & 30 & 30 & 30 \\
\hline Sprayer & 70 & 70 & 70 \\
\hline Total assets/investment ${ }^{A}$ & 4510.7 & 4510.7 & 4510.7 \\
\hline \multicolumn{4}{|l|}{ Analysis of return on key resources } \\
\hline Net farm profit ${ }^{B}$ & 5103.5 & 4462.1 & 4824 \\
\hline Interest expenses & - & - & - \\
\hline $\begin{array}{l}\text { Value of unpaid labour and } \\
\text { management }{ }^{C *}\end{array}$ & 3660 & 3268 & 3787 \\
\hline Return to assets $(A-B)^{D}$ & 1514 & 895 & 1037 \\
\hline $\begin{array}{l}\text { Rate of return on investment } \\
\text { (ROI) } \\
\text { (D/A) } \%\end{array}$ & 29.1 & 21.2 & 24.1 \\
\hline $\begin{array}{l}\text { Opportunity cost of unpaid } \\
\text { labour and mgt }\end{array}$ & 3660 & 3268 & 3787 \\
\hline $\begin{array}{l}\text { Opportunity cost of capital } \\
\text { (at 25\%) }\end{array}$ & 1127.7 & 1127.7 & 1127.7 \\
\hline Total capital less land & 226.7 & 226.7 & 226.7 \\
\hline $\begin{array}{l}\text { Opportunity cost of capital } \\
\text { less land }\end{array}$ & 56.7 & 56.7 & 56.7 \\
\hline Return to land & 1457.3 & 838.3 & 980.3 \\
\hline $\begin{array}{l}\text { Return to unpaid labour and } \\
\text { mgt }\end{array}$ & 4046.3 & 3035.3 & 3696.3 \\
\hline $\begin{array}{l}\text { Return to per unit unpaid } \\
\text { labour and mgt }\end{array}$ & 25.3 & 21.7 & 24.6 \\
\hline
\end{tabular}

* Values represent the opportunity costs for operator (household) labour and management on cocoyam farms for the various cropping systems practised GHC $1.00=$ USD 0.29 (BoG, 2016)

Cultivating cocoyam as a sole crop was economically sound than as an intercrop given the return on assets under the two systems (29.1 and $21.2 \%$, respectively). Analysis based on the cropping systems revealed that producers who cultivated the root crop on a sole crop basis earned GH\& 1457.3 as returns to (per hectare) land committed to growing cocoyam. The return to a hectare of land for farmers who cultivated cocoyam as an intercrop averaged GH\$ 838.3. Thus, a profit of GH\$ 838.3 was recorded for farmers using their lands to cultivate cocoyam as an intercrop, signifying positive land productivity similar to the sole cropping system. However, the relatively low return to land under the intercropping system can be attributed to production inefficiencies and the seeming lack of proper resource allocation under the cropping system. Averagely, the returns to labour and management for farmers who cultivated cocoyam as a sole crop were GHष 4046.3 which translates into GH4 25.3 per day. Cocoyam cultivated as an intercrop returned an amount of GHC 3035.3 to farmer's own labour and management which also translates into $\mathrm{GHC}$ 21.7 daily. Although the total cost of production did not significantly differ with respect to production systems, gross margins, net income and returns to critical production factors under the mono-cropping system were found to be significantly higher, at $5 \%$ significance level, compared to the intercropping system. Table 11 summarises the statistical difference of variables of interest with respect to the two production systems.

\section{Conclusions and recommendations}

The study sought to assess the economics of cocoyam production in Ghana. This was motivated by the need to understand the dynamics of cocoyam production and to determine whether its production was financially attractive. Based on the findings, the study concludes that cocoyam cultivation is generally done on a small scale at an average of 0.55 hectares per cropping season, constituting about $13 \%$ of the total agricultural land managed by producing households and about $19 \%$ of the total cultivated land of cocoyam producers. The root crop, whose main target produce is the corms, is cultivated equally for household consumption and for commercial purposes and mostly used as an intercrop to plantain, cocoa and cassava. Cocoyam production is largely a woman's enterprise; however, production was dominated by male farmers in the Fanteakwa district.

Labour was found to be the most important cost component accounting for more than half (54\%) of the total cost of production in cocoyam production with harvesting and weed control among the most labour-intensive activities of cocoyam production. Cocoyam production returned an average gross margin of GH\$ 5164 and net farm profit of GH4 4824 per hectare. Revenue from the sale of cocoyam leaves accounted for $11 \%$ of the total cocoyam revenue. Presently, with a return on asset of $24 \%$, cocoyam production was not financially attractive given the prevailing cost of capital in the Ghanaian economy (25\%). Any GHd 1.00 invested into cocoyam production returned a net profit of GHC 0.24 ceteris paribus. Similar to other food crops, smallholder producers who cultivate the root crop for the sole objective of satisfaction or household food security will continue to produce it, nonetheless.

Disaggregated data revealed production to be rather profitable in the Fanteakwa district explaining the maledominated nature of production in that district. The 
Table $11 T$ test results for selected variables (by cropping system)

\begin{tabular}{|c|c|c|c|c|c|}
\hline Variable & Cropping system & Mean per ha & SD & Mean difference ${ }^{a-b}$ & T-statistic \\
\hline \multirow[t]{2}{*}{ Yield per ha (corms + leaves) } & Solecrop ${ }^{\mathrm{a}}$ & 7042 & 3631.71 & 1057 & $6.53^{* *}$ \\
\hline & Intercrop ${ }^{b}$ & 5985 & 6052.63 & & \\
\hline \multirow[t]{2}{*}{ Total production cost } & Solecrop & 3469 & 1642.44 & 124 & 2.06 \\
\hline & Intercrop & 3345 & 1601.52 & & \\
\hline \multirow[t]{2}{*}{ Gross margin } & Solecrop & 5420.5 & 4897.16 & 616.4 & $6.18^{* *}$ \\
\hline & Intercrop & 4806.1 & 4950.94 & & \\
\hline \multirow[t]{2}{*}{ Net income (corm only) } & Solecrop & 4876 & 4008.23 & 1413 & $7.26^{* *}$ \\
\hline & Intercrop & 3463 & 3121.11 & & \\
\hline \multirow[t]{2}{*}{ Total net income (corm + leaves) } & Solecrop & 5103.5 & 4038.99 & 641.1 & $3.77^{* *}$ \\
\hline & Intercrop & 4462.1 & 3957.54 & & \\
\hline \multirow[t]{2}{*}{ Return on assets } & Solecrop & 29.1 & 10.19 & 7.9 & $4.16^{* *}$ \\
\hline & Intercrop & 21.2 & 19.13 & & \\
\hline \multirow[t]{2}{*}{ Returns to land } & Solecrop & 1457.3 & 911.78 & 619 & $8.03^{* *}$ \\
\hline & Intercrop & 838.3 & 665.81 & & \\
\hline \multirow[t]{2}{*}{ Return to unpaid labour and mgt } & Solecrop & 4046.3 & 3155.96 & 1011 & $4.21^{* *}$ \\
\hline & Intercrop & 3035.3 & 2971.68 & & \\
\hline
\end{tabular}

** Significant scores at 5\% significance level

study concludes that Fanteakwa farmers are better off than their counterparts mainly due to the significantly higher yield and market price per $\mathrm{kg}$ of produce, whereas producers in the Asunafo North district are better off than those in Asante Akyem South mainly due to the relatively higher output per hectare of cocoyam cultivated. Furthermore, the study found that producing cocoyam as a sole crop was relatively more profitable than under the intercropping system. Producers who cultivated cocoyam on a sole crop basis earned average net income of GH4 5174 translating into a ROI of about 29\%, whereas farmers that produced cocoyam as an intercrop earned GH4 0.21 more as profit for any one Ghana cedi invested.

Revenue from cocoyam leaves accounted for $13.4 \%$ of the total cocoyam revenue earned under the intercropping systems compared to about $7 \%$ under the sole cropping system. Producers earned an average of GHC 980 and 3696 per hectare per cropping season, as returns to land as well as unpaid labour and management, respectively, with producers from Fanteakwa district receiving relatively higher returns to these resources. This compared higher than the prevailing rent per hectare (GH4 $180)$ and wage rate (GHC 13), indicating that cocoyam farmers have a better financial leverage for their land and labour when they cultivate cocoyam than to rent out or work on other on- or off-farm enterprises. Gross margin, net income and returns to critical production factors under the mono-cropping system were found to be significantly higher relative to the intercropping system.

\section{Policy recommendations}

The use of improved planting materials (early maturing and high yielding) is crucial towards increasing output and income from cocoyam. In order for cocoyam production to be competitive, the study recommends development and distribution of improved cocoyam planting materials for farmers to access and improve output. Policies directed at encouraging and improving access and intensification of productive inputs should also be considered. Cocoyam production is predominantly cultivated by women farmers who are often resource-poor and lack access to productive resources. The study recommends a concerted effort by policy makers to target and empower women farmers to help them gain access to capital, land for increased yield and income. Given the competitive advantage and financial attractiveness of cocoyam production in Fanteakwa and Asunafo North, other entrepreneurs within in that district should be sensitised on the economic prospects to venture into cocoyam production.

Lastly, for producers to harness the financial benefits of cocoyam, producers are encouraged to cultivate cocoyam as sole crop over the intercropping system. This does not suggest a wholesale elimination of the mixed cropping systems across cocoyam growing communities. Farmers who often intercrop cocoyam can henceforth be encouraged to allot similar portions of their cultivated lands (as they used to under intercropping system) to sole cropping cocoyam. This way, they still get to cultivate a cocktail of crops which ensure household food security and spread risk while improving yield and income from 
cocoyam at the same time. In order to minimise labour cost, the study proposes the development of cost-effective labour-saving technologies (especially for harvesting and weeding) easily adoptable by small-scale cocoyam producers to make production less labour-intensive.

\begin{abstract}
Abbreviations
AAS: Asante Akyem South District; AN_D: Asunafo North District; F_D: Fanteakwa District; MoFA: Ministry of Food and Agriculture; SDG: Sustainable Development Goals; RTIMP: Root and Tuber Improvement and Marketing Programme; RTIP: Root and Tuber Improvement Programme; SRID: Statistical Research and Information Directorate; WAAPP: West African Agricultural Productivity Programme.
\end{abstract}

\section{Authors' contributions}

This paper was conceived and developed by SBA with significant guidelines and intellectual contributions from KOY, RA and OJS. All authors read and approved the final manuscript.

\section{Authors' information}

SBA is a Research Assistant and Assistant Project Administrator of the 'Strengthening Root and Tuber Value Chains in Ghana' project at the Department of Agricultural Economics, Agribusiness and Extension, KNUST. RA is a Researcher and Principal Investigator of the 'Strengthening Root and Tuber Value Chains in Ghana' project at the Department of Agricultural Economics, Agribusiness and Extension, KNUST. KOY is a Researcher at the Department of Agricultural Economics, Agribusiness. OJS is a professor of International Business and Economics at the International Business Centre, Aalborg University.

\section{Author details}

1 Department of Agricultural Economics, Agribusiness and Extension, Kwame Nkrumah University of Science and Technology (KNUST), Private Mail Bag, Kumasi, Ghana. ${ }^{2}$ Aalborg University, Aalborg, Denmark.

\section{Acknowledgements}

The research was undertaken under the project'Strengthening Root and Tuber Value Chains in Ghana'financed by the Danish Development Agency (DANIDA) through the DFC. Authors would like to thank DANIDA for the sponsorship. The authors gratefully acknowledge the data collection team, extension officers, community authorities and the smallholder farmers-especially the women farmers, for their collaboration and contributions. But for them, this study would not have been possible. We wish to acknowledge the comments and review of the two anonymous reviewers.

\section{Competing interests}

The authors declare that they have no competing interests.

\section{Availability of data and materials}

The data that support the findings of this study are available from the Root and Tuber Value Chain project but restrictions apply to the availability of these data, which were used under licence for the current study, and so are not publicly available as of yet. Data are, however, available from the authors upon reasonable request and with permission of the said project.

\section{Ethics approval and consent to participate}

The study received ethics approval from the Ministry of Food and Agriculture District Directorates of the study districts. Official extension officers were assigned to aid with the survey facilitation. Informed consent was given verbally by each research participant prior to the application of any research procedures (survey).

\section{Funding}

This research was supported with funds from DANIDA under the project 'Strengthening Root and Tuber Value Chain in Ghana' (12-P08-GHA).

\section{Publisher's Note}

Springer Nature remains neutral with regard to jurisdictional claims in published maps and institutional affiliations.
Received: 18 November 2016 Accepted: 9 May 2017

Published online: 15 June 2017

\section{References}

1. Onyeka J. Status of cocoyam (Colocasia esculenta and Xanthosoma spp.) in West and Central Africa: production, household importance and the threat from Leaf Blight. CGIAR Research Program on Roots, Tubers and Bananas (RTB). 2014.

2. Azeez AA, Madukwe OM. Cocoyam production and economic status of farming households in Abia state, South-East, Nigeria. J Agric Soc Sci. 2010;6:83-6.

3. MoFA-SRID. Agriculture in Ghana: facts and figures 2012. Statistics, research and information directorate. Ministry of Food and Agriculture, Accra, Ghana. 2013

4. FAOSTAT. Production statistics Ghana, Cameroon, Nigeria-Taro (cocoyam). FAO. http://knoema.com/FAOPRDSC2015Feb/production-statisticscrops-crops-processed-february-2015 on 12/09/2015. Accessed 12 Feb 2015.

5. Quaye W, Adofo K, Agyeman KO, Nimoh F. Socioeconomic survey of traditional commercial production of cocoyam and cocoyam leaf. Afr J Food Agric Nutr Dev. 2010;10(9):4060-78.

6. Talwana HAL, Serem AK, Ndabikunze BK, Nandi JOM, Tumuhimbisel R, Kaweesil T, Chumo EC, Palapala V. Production status and prospects of cocoyam (Colocasia esculenta (L.) Schott.) in East Africa. J Root Crops Indian Soc Root Crops. 2009;35(1):98-107.

7. Acheampong PP, Osei-Adu J, Amengo E, Sagoe R. Cocoyam value chain and benchmark study in Ghana. A report submitted to West African Agricultural Productivity Project (WAAPP). Project Information Document, 2014, pp. 7-11.

8. RTIMP. Annual report for 2013. Root and Tuber improvement and marketing programme, Ministry of Food and Agriculture, Accra, Ghana, 2014.

9. Sam J, Dapaah H. Baseline survey report: West African Agricultural Productivity Programme (WAAPP). Ghana, 2009.

10. Ghana Statistical Service. 2012 Population and Housing Census. Summary report of final results. Accra: Sakoa Press Limited; 2014.

11. Shiyam JO, Oko BFD, Obiefuna JC, Ofoh MC. Optimizing the productivity of plantain/cocoyam mixture by mulching and fertilizers application. World J Fungal Plant Biol. 2010;1(2):42-5.

12. Asumadu H, Omenyo EL, Tetteh F. Physiological and economic implications of leaf harvesting on vegetative growth and cormel yield of cocoyam (Xanthosoma sagittifolium). J Agron. 2011;10(4):112-7.

13. Sagoe R, Haleegoah J, Marfo KA. Economic evaluation of cocoyam (Xanthosoma sp.) and maize (Zea mays) in a mixed cropping system. Ghana J Agric Sci. 2007;39(2):171-80.

14. Falola A, Fakayode S, Banjoko K. Economic analysis of cocoyam production in Osun State. Nigeria. Ilorin J Econ Policy. 2014;1(1):30-40.

15. Gbigbi MT. Cocoyam production beyond subsistence: does it have income increasing capacity for poverty reduction in Delta State, Nigeria. J Basic Appl Res Int. 2015;5(4):207-13.

16. Adepoju AA, Awodunmuyila DJ. Economics of cocoyam production and marketing in Ekiti East Local Government Area, Ekiti State, Nigeria. Res J Appl Sci. 2008;3(2):95-8.

17. Ajijola S, Ajani OI, Saka JO. Efficiency of resource use among cocoyam farmers in Owo Local Government Area of Ondo State. Nigeria. Moor J Agric Res. 2003;4(2):281-7.

18. Okoye BC, Asumugha GN, Mbanaso ENA. Cost return analysis of cocoyam production at NRCRI, Umudike. Agric Soc Nigeria. 2006;41:511-3.

19. Beattie $A . F Y I$ on ROI: a guide to calculating return on investment. http:// www.investopedia.com/articles/basics/10/guide-to-calculating-roi.asp. Accessed 14 July 2016.

20. Kay RD, Edwards WM, Duffy PA. Farm management. 5th ed. New York: Mc-Graw-Hill; 2004.

21. Kohl D, Wilson T. Understanding key financial ratios and benchmarks. Spokane, WA: Business Tools Bulletin, Northwest Farm Credit Services; 1997.

22. McConnell DJ, Dillon JL. Farm management for Asia: a systems approach (No. 13). Rome: Food \& Agriculture Organization; 1997. 
23. Bank of Ghaana. Markets: Daily interest rates. Bank of Ghana. https:// www.bog.gov.gh/index.php?option=com_wrapper\&view=wrapper\&lte mid=255. Accessed 10 Aug 2016.

24. Ijioma JC, Effiong JB, Ogbonna MO, Onwuamaoka EA. Determinants of adoption of selected NRCRI cocoyam technologies among farmers in Umuahia South Local Government Area of Abia State, Nigeria. Am Int J Contemp Res. 2014;4(6):182-9.

25. Ikwelle MC, Ezulike TO, Eze OO. Contribution of root and tuber crops to the Nigeria economy. In: Proceedings of the 8th triennial symposium of the international society for tropical Root Crops. Africa Branch (ISTRC-AB) held at the IITA, Ibadan. 2003. p. 13-18.

26. Polson RA, Spencer DS. The technology adoption process in subsistence agriculture: the case of cassava in Southwestern Nigeria. Agric Syst. 1991;36(1):65-78
27. Jegede CT. The role of education in technology transfer and poverty reduction in Nigeria. J Sci Technol. 2008;28(1):146-56.

28. International Institute of Tropical Agriculture. Annual report 2013. IITA, Ibadan, Nigeria. IITA; 2013. p. 31. ISSN 0331 4340. http://www.iita. org/c/document_library/get_file?uuid=13c58fa0-6321-4850-8c53f0a667e6a1d2\&groupld=25357. Accessed 5 Mar 2016.

29. Mohammed AB, Ayanlere AF, Ibrahi U, Lawal AM. Economic analysis of maize production in Ogori Magongo Local Government area of Kogi State, Nigeria. J Agric Econ Dev. 2013;1(3):33-56.

30. Kaine AIN, Okoje LJD. Estimation of costs and return of plantain production in Orhionmwon Local Government Area, Edo State, Nigeria. Asian J Agric Rural Dev. 2014;4(2):162-8.

\section{Submit your next manuscript to BioMed Central and we will help you at every step:}

- We accept pre-submission inquiries

- Our selector tool helps you to find the most relevant journal

- We provide round the clock customer support

- Convenient online submission

- Thorough peer review

- Inclusion in PubMed and all major indexing services

- Maximum visibility for your research

Submit your manuscript at www.biomedcentral com/submit 